\title{
Congenital long QT syndrome in children
}

\section{Kongenitalni sindrom produženog QT intervala kod dece}

\author{
Ivana Cerovićl, Jovan Košutić ${ }^{2}$
}

${ }^{1}$ Faculty of Medicine, University of Belgrade, Serbia

${ }^{2}$ Institute for Mother and Child Health Care of Serbia „Dr Vukan Čupić“

\section{Apstrakt}

Sindrom produženog QT intervala (engl. long QT syndrome, LQTS) je poremećaj repolarizacije komora miokarda koji se odlikuje produženjem QT intervala na elektrokardiogramu (EKG) i povećanim rizikom za nastanak ventrikularnih tahiaritmija i kardiogenih manifestacija. Može da bude stečeni ili kongenitalni, koji predstavlja skup kanalopatija usled mutacija u nekom od 15 do sada identifikovanih gena. Najčešći oblici kongenitalnog sindroma su LQT1, LQT2 i LQT3. Zbog produženja repolarizacije i, posledično, celog akcionog potencijala, stvaraju se uslovi za nastanak rane naknadne depolarizacije i izraženije transmuralne disperzije repolarizacije koje su, pojedinačno ili udruženo, osnova za nastanak Torsades de pointes ventrikularne tahikardije. Sindrom produženog QT intervala se klinički manifestuje palpitacijama, sinkopom, srčanim zastojem ili naprasnom srčanom smrću, a može da bude i asimptomatski. Provocirajući faktori za nastanak tegoba su specifični za određeni genotip. Ispitivanje LQTS obuhvata ličnu i porodičnu anamnezu sa naglaskom na karakteristične podatke (česte sinkope, iznenadna srčana smrt u porodici, nasledne aritmije), EKG u miru, test opterećenja i genetske analize, kao i druge dodatne metode (serijski EKG zapisi, 24h EKG holter, epinefrinski test). Za kliničko postavljanje dijagnoze koristi se Švarcov (Schwartz) skor, a kriterijumi za definitivno postavljanje dijagnoze zavise od Švarcovog skora, dužine QT intervala, postojanja mutacije i kliničke slike. Lečenje se zasniva na promeni životnih navika i terapiji $\beta$-blokatorima, a druge mogućnosti su ugradnja implantabilnog kardioverter-defibrilatora, permanentnog pejsmejkera ili hirurška simpatektomija. Sindrom produženog QT intervala je jedan od potencijalnih uzroka iznenadne srčane smrti koja čini $90 \%$ iznenadnih smrti mladih sportista. Kod dece sa LQTS preporuke za bavljenje sportom proizilaze iz preporuka za odrasle i podrazumevaju vrlo stroga ograničenja. Dalja istraživanja biće usmerena na bolje razumevanje genotip-fenotip korelacije kongenitalnih LQTS i očekuje se da će pružiti nove personalizovane terapijske mogućnosti i saznanja o ređim tipovima ovog sindroma, kao i jasnije preporuke za bavljenje fizičkom aktivnošću kod dece sa LQTS.

KIjučne reči: sindrom produženog QT intervala, deca, genetika, fizička aktivnost

\section{Abstract}

Long QT syndrome (LQTS) is a cardiac repolarization disorder characterized by prolonged QT interval on the electrocardiogram (ECG) and increased propensity to ventricular tachyarrhythmias and cardiac events. LQTS might be acquired or congenital, which presents a group of channelopathies that occur due to mutation in one of 15 so far identified genes. The most frequent types of congenital LTQS are LQT1, LQT2 and LQT3. Prolonged or delayed repolarization leads to the increase of action potential duration which predisposes early afterdepolarization, as well as the amplification of transmural dispersion of repolarization, both contributing to the development of Torsades de Pointes ventricular tachycardia. Clinical manifestations of LQTS are palpitations, syncope, aborted cardiac arrest or sudden cardiac death, but it can also be asymptomatic. Trigger factors for symptoms are specific for certain genotype. LQTS examination includes thorough clinical and family history focused on distinctive data (repeated syncopes, cases of sudden cardiac death in the family, hereditary arrhythmias), resting ECG, exercise stress testing and genetic analysis, with additional methods (serial ECG records, 24h ECG Holter, epinephrine test). Clinical LQTS diagnosis is based on Schwartz's scoring system, while the criteria for final diagnosis of LQTS depend on Schwartz's score, QT interval duration, presence of pathogenic mutation and clinical symptoms. Treatment approach begins with lifestyle modifications and $\beta$-blockers therapy, while other options include implantable cardioverter-defibrillator, permanent pacemaker or surgical sympathectomy. Sudden cardiac death is the reason of $90 \%$ of sudden deaths in young athletes, while LQTS is one of its causes. Recommendations for physical activities in children with congenital LQTS arise from the ones for adults and they presume very strict limitations. Further researches are expected to advance the understanding of genotype-phenotype correlation of congenital LQTS and enable eventual genetically-guided personalized treatment, novel insight into rare LQTS types, as well as more precise recommendations for physical activity of LQTS children.

Key words: long QT syndrome, children, genetics, physical activity 


\section{Introduction}

Long QT syndrome (LQTS) is a cardiac repolarization disorder characterized by prolonged QT interval on the electrocardiogram (ECG) and increased propensity to ventricular tachyarrhythmias (Torsades de pointes (TdP) tachycardia and ventricular fibrillation (VF)) (figure 1a). It can be asymptomatic or clinically manifested as palpitations, syncope, aborted cardiac arrest (ACA) or sudden cardiac death (SCD) (1). LQTS might be congenital or acquired, with potential causes including myocardial ischemia, cardiomyopathy, certain drug consumption (antiarrhytmics, antibiotics, antidepressives, antipsychotics, etc), hypokalemia or hypomagnesaemia (2). Congenital LQTS presents a group of monogenic, predominantly autosomal-dominant (A-D) channelopathies or other proteinopathies, denominated as LQT1-LQT15, according to 15 so far identified genes known to be associated with LQTS (table 1) (3). The estimated prevalence of 1:2000 subjects is supposed to be even greater on the behalf of subclinical forms, while about $50 \%$ of eventually symptomatic LQTS patients experience their first cardiac event by the age of 12 (4). Also, in $10 \%$ of cases of sudden infant death syndrome (SIDS) is proven a LQTS-gene mutation (5).

\section{Genetic and molecular basis}

In $75 \%$ of non-acquired LQTS is found a causal mutation (6), out of which $85 \%$ are inherited and the remaining occur de novo (7). The most common forms are LQT1, LQT2 and LQT3, constituting about $90 \%$ of genetically proven cases (1). These mutations cause alterations in specific ion channels which participate in action potential, leading to the delay of repolarization process.

LQT1, the most common form present in about $45 \%$ of genotyped patients, arises from the loss of function in KCNQ1 gene, which encodes $a$-subunit of the slow activating potassium channel, responsible for slow delayed rectifier potassium current (IKs) (7). LQT2, with frequency of $35-40 \%$, stems due to mutation in KCNH2 gene, encoding the $\alpha$-subunit of potassium channel responsible for rapid delayed rectifier potassium current (IKr) (7). There are two mechanisms mediating the reduction of repolarizing current and ensuing delayed repolarization in potassium channel mutations: 1) trafficking defect, when mutant subunits are not transported or incorporated properly in tetrameric channel; and 2) formation of defective channels, resulting in $>50 \%$ reduction in channel current (8). On the other hand, LQT3 results from gainof-function mutation in SCN5A gene which encodes rap-

Table 1. Congenital LQTS genes, affected proteins and ion currents (3).

\begin{tabular}{|c|c|c|c|c|c|}
\hline LQTS type & Gene & Protein & Protein function & Current & Frequency (\%) \\
\hline LQT1 & KCNQ1 & Kv7.1 & a-subunit IKs channel & $\downarrow \mathrm{IKs}$ & $40-55$ \\
\hline LQT2 & KCNH2 & Kv11.1 & $\alpha$-subunit IKr channel & $\downarrow \mathrm{IKr}$ & $30-45$ \\
\hline LQT3 & SCN5A & Nav1.5 & $\alpha$-subunit INa channel & $\uparrow \mathrm{INa}$ & $5-10$ \\
\hline LQT4 & ANKB & Ankyrin & Adaptor protein & $\begin{array}{l}\downarrow \text { Coordination of Ncx, } \\
\text { Na/K ATPase }\end{array}$ & Rare \\
\hline LQT5 & KCNE1 & $\operatorname{MinK}$ & $\beta$-subunit $I$ Ks channel & $\downarrow \mathrm{IKs}$ & Rare \\
\hline LQT6 & KCNE2 & MiRP1 & $\beta$-subunit IKr channel & $\downarrow \mathrm{IKr}$ & Rare \\
\hline LQT7 & $\mathrm{KCNJ} 2$ & Kir2.1 & $\alpha$-subunit IK1 channel & $\downarrow$ IK1 & Rare \\
\hline LQT8 & CACNA1C & Cav1.2 & $\alpha$-subunit ICaL channel & $\uparrow \mathrm{ICa}$ & Rare \\
\hline LQT9 & CAV3 & Caveolin 3 & $\begin{array}{l}\text { Component of caveolae } \\
\text { (co-localizes with Nav1.5) }\end{array}$ & $\uparrow \mathrm{INa}$ & Rare \\
\hline LQT10 & SCN4B & $\beta 4$-subunit & $\beta$-subunit INa channel & $\uparrow \mathrm{INa}$ & Very rare \\
\hline LQT11 & AKAP9 & Yotao & $\begin{array}{l}\text { Mediates Kv7.1 phosphor- } \\
\text { ylation }\end{array}$ & $\downarrow \mathrm{IKs}$ & Very rare \\
\hline LQT12 & SNTA1 & Syntrophin- $\alpha 1$ & $\begin{array}{l}\text { Regulates INa channel } \\
\text { function }\end{array}$ & $\uparrow \mathrm{INa}$ & Very rare \\
\hline LQT13 & KCNJ5 & Kir3.4 & Subunit KACh channel & $\downarrow \mathrm{IK}-\mathrm{ACh}$ & Very rare \\
\hline LQT14 & CALM1 & Calmodulin 1 & Calmodulin & $\begin{array}{l}\text { Dysfunctional } \mathrm{Ca}^{2+} \\
\text { signaling }\end{array}$ & Rare \\
\hline LQT15 & CALM2 & Calmodulin 2 & Calmodulin & $\begin{array}{l}\text { Dysfunctional } \mathrm{Ca}^{2+} \\
\text { signaling }\end{array}$ & Rare \\
\hline
\end{tabular}


idly inactivating sodium channel, so the channel fails to close properly; continuous inward leakage of sodium ions prolongs plateau phase and therefore delays repolarization (8).

\section{Mechanisms of ventricular tachyarrhythmias development}

Ventricular myocardium is comprised of at least three electrophysiologically and functionally distinct cell types - epicardial, M and endocardial cells, which show electrical heterogeneity in the form of transmural dispersion of repolarization (TDR), under baseline conditions (9). Prolonged or delayed repolarization leads to the increase of action potential duration (APD) which, due to higher intracellular concentration of calcium, during phases 2 or 3 of action potential, predisposes early afterdepolarization (EAD) (10). Agents that prolong APD produce preferential prolongation of the $\mathrm{M}$ cell action potential than of the epicardial or endocardial cells, leading to the amplification of TDR (11). That creates a vulnerable window for the development of reentry phenomenon as well as EAD, both contributing to the development of TdP (figure 1b) (11). Depending on the duration, TdP can progress to ventricular fibrillation or cardiac arrest.

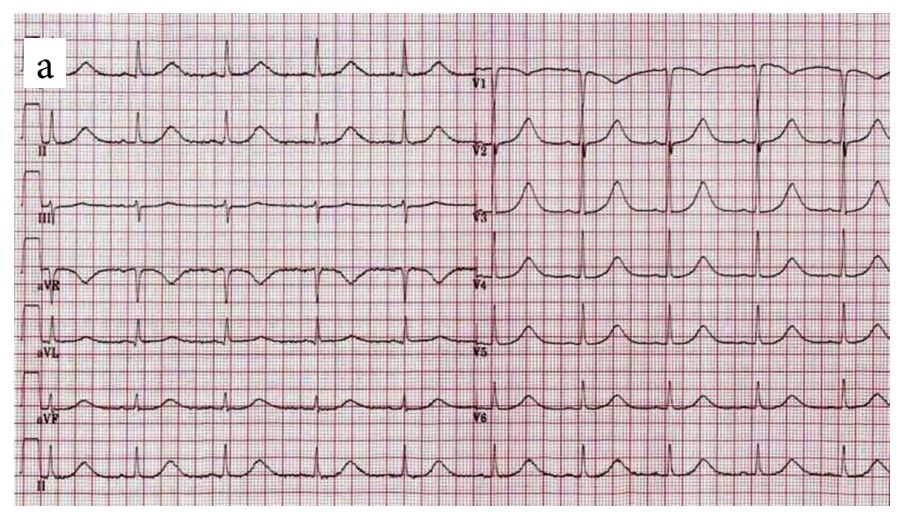

$\mathrm{b}$

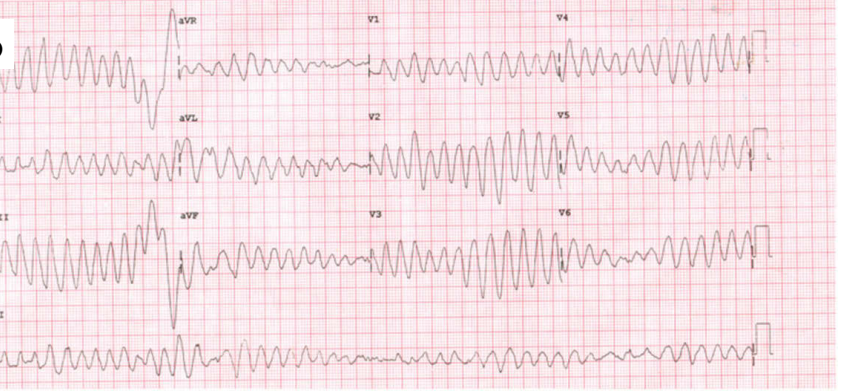

Figure 1. Representative ECG findings: a) prolonged QT interval; b) Torsades de pointes.

\section{Clinical presentation}

The most frequent symptoms of LQTS are palpitations and syncope. However, it can be an accidental ECG finding in an asymptomatic patient, while ACA or SCD as the first manifestation of the disease occur in 1-3\% (3). Clinical presentation depends on inheritance pattern, genetic polymorphism, penetrance and modifier genes, as well as the age, gender, environmental factors and therapy (3).

Congenital LQTS can be phenotypically classified into four syndromes. The most common is A-D inherited Romano-Ward syndrome, which may result from a mutation in any of LQTS genes and it has the widest range of cardiac manifestations (7). Jervell and Lange-Nielsen (JLN) syndrome is a rare autosomal recessive (A-R) disease caused by homozygous mutation in KCNQ1, associated with congenital deafness and very severe form of LQTS (12). Andersen-Tawil syndrome, known as LQT7, is a rare A-D condition characterized by hypokalemic periodic paralysis, ventricular tachyarrhythmias and a variety of dysmorphic features (13). Tymothy syndrome (LQT8) is the consequence of CACNAlc gene mutation, manifested with LQTS, facial dysmorphia, syndactilia and neurocognitive insufficiency (14).

Specific triggers are associated with certain LQTS types. Physical exertion, especially swimming, and emotional stress contribute to LQT1symptoms, due to the lack of compensatory IKs increase in adrenergic stimulation (15). Possible explanations for the particular role of swimming include concomitant activation of sympathetic and parasympathetic autonomic system precipitating premature ventricular contractions, as well as QT interval prolongation due to cold-water face immersion, which both contribute to genetically caused IKs-deficiency (16). Most events in LQT2 and LQT3 are provoked by acute arousal/ auditory stimulation or rest without arousal, respectively (17). Nevertheless, comorbidity of epilepsy with LQT2 due to KCNH2 expression in brain makes their differential diagnosis very important for therapeutic approach (18).

\section{Diagnostic methods and criteria for LQTS}

The diagnostic process begins with a thorough clinical and family history, focused on distinctive data about palpitations, repeated syncopes and their circumstances, "seizures" despite antiepileptic therapy, cases of SCD in the family or hereditary arrhythmias (7). Certain number of LQTS is revealed due to previous diagnosis of a family member.

Resting ECG with QT interval duration measurement remains crucial for the diagnosis. QT interval is usually corrected for heart rate using the Bazett's formula, 
$\mathrm{QTc}=\mathrm{QT} / \sqrt{\mathrm{RR}}$, expressed in milliseconds (ms), measured in leads II and V5/V6, with the longest value being used (18). Since there is no cut-off QTc value for LQTS, different authors give their references. According to the latest recommendations by the American College of Cardiology, the American Heart Association and the Heart Rhythm Society (AHA/ACCF/HRS) from 2009, prolonged QTc is considered $\geq 450 \mathrm{~ms}$ for adult male and $\geq 460$ msfor adult female (19), while another study suggests borderline QTc $\geq 470 \mathrm{~ms}$ for adult female and $\geq 460 \mathrm{~ms}$ for children under the age of 15 (table 2) (20). However, single ECG assessment could not be reliable, since $2.5 \%$ of healthy population may have a mildly prolonged QT interval and $25 \%$ of genotype-positive LQTS patients have normal QT interval, especially LQT1 (21). Besides, T wave morphology may help differentiate diverse types of LQTS (22). Usual ECG findings in fetal and neonatal LQTS are bradycardia and atrioventricular block (23).

Table 2. Suggested Bazett-corrected QTc values for diagnosing QT prolongation [ms] (19).

\begin{tabular}{llll}
\hline Rating & $1-15$ years & Adult male & Adult female \\
\hline Normal & $<440$ & $<430$ & $<450$ \\
Borderline & $440-460$ & $430-450$ & $450-470$ \\
Prolonged & 460 & 450 & 470 \\
\hline
\end{tabular}

Exercise stress testing (EST) may help identifying abnormal QT prolongation during exercise or in the recovery, as well as the level of physical activity allowed to patients with LQTS. Pediatric population is characterized by more gradual deceleration in heart rate in recovery phase compared to the adults (24). The same study indicates that prolonged QT interval at peak exercise, in early (1-min) and late (7-min) recovery phase occurs in LQT1, while initial shortening and afterwards prolongation of QT interval in late recovery phase suggest LQT2 (24). QTc threshold value of $\geq 460 \mathrm{~ms}$ in late recovery phase in children strongly refers to the LQTS and greater separation in the QTc intervals between the late and early recovery phases favors the diagnosis of LQT2 (24).

Additional diagnostic methods include serial ECG records, 24h ECG Holter and epinephrine test (8). Moreover, genetic analysis, which can confirm approximately $75 \%$ of phenotypically expressed LQTS, still remains to be widely established for clinical use (25). Negative genetic test does not exclude the diagnosis, whereas positive result may influence treatment decisions.

Considering the diagnostic adversity, Schwartz et al defined the scoring system (last revision in 2011), which assign points for ECG findings, clinical and family history (table 3) (26). Patients with Schwartz score $\geq 3.5$, in the absence of secondary cause for QT prolongation, are di- agnosed as LQTS (26). Although it would miss the latent LQTS patients, this system presents the basis of clinical LQTS diagnosing.

Table 3. Schwartz Score for LQTS diagnosis (updated in 2011) (25).

\begin{tabular}{lc}
\hline & Points \\
\hline ECG findings & \\
QTc & 3 \\
$\quad>480 \mathrm{~ms}$ & 2 \\
$\quad 460-470 \mathrm{~ms}$ & 1 \\
$\quad 450$ (male) ms & 1 \\
4-min recovery QTc after exercise test $\geq 480 \mathrm{~ms}$ & 2 \\
Torsades de pointes & 1 \\
T-wave alternans & 1 \\
Notched T wave in 3 leads & 0.5 \\
Low heart rate for age & \\
Clinical history & \\
Syncope & 2 \\
$\quad$ With stress & 1 \\
$\quad$ Without stress & 0.5 \\
Congenital deafness & \\
Family history & \\
Family members with definite LQTS & 1 \\
Unexplained sudden cardiac death <age 30 & 0.5 \\
among immediate family members &
\end{tabular}

QTc is calculated by Bazett's formula. Low heart rate for age means resting heart rate below the 2 nd percentile for age.

Expert consensus published in 2013 defined criteria for the diagnosis of LQTS, which include: 1) Schwartz's score $\geq 3.5$ in the absence of a secondary cause for QT prolongation; 2) presence of pathogenic mutation in one of the LQTS genes; 3) QTc $\geq 500 \mathrm{~ms}$ in repeated 12- lead ECG in the absence of a secondary cause for QT prolongation; 4) QTc between 480 and $499 \mathrm{~ms}$ in repeated 12-lead ECGs in a patient with unexplained syncope, in the absence of a secondary cause for QT prolongation and pathogenic mutation (27).

\section{Risk stratification}

Risk assessment for a life-threatening cardiac event has the main role in the treatment planning. Higher risk of cardiac manifestations have boys under the age of 15 with LQT1, while for LQT2 and LQT3 in that age the risk is equal for both genders (28). Over 15 years old females are at higher risk in LQT1 and LQT2, and possible explanation for this sex distribution lies in sex hormones, inhibitory effect of estrogen on $\mathrm{IKr}$ and stimulatory effect of testosterone on IKs, with ensuing prolongation and shortening of APD, respectively (29). Furthermore, LQT3 patients have lower incidence of any type of cardiac event, 


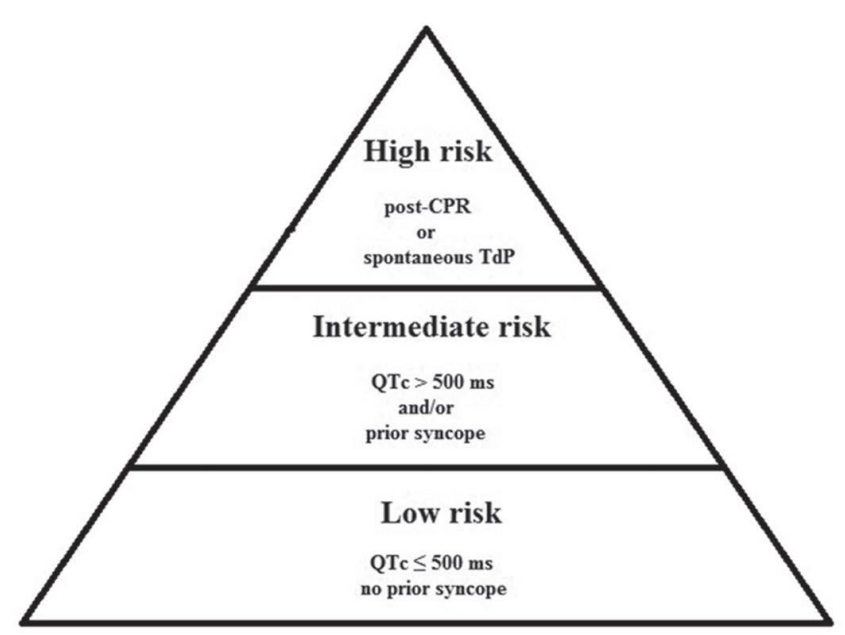

CPR -cardiopulmonary resuscitation.

TdP - Torsades de Pointes

Figure 2. Suggested risk stratification scheme for aborted cardiac arrest or sudden cardiac death in LQTS patients(30).

but followed with much higher lethality (3). Baseline QTc $\geq 500 \mathrm{~ms}$ is an independent risk factor (19). The history of syncope and their frequency is one of the most powerful predictors of subsequent serious cardiac events in adolescents (30). Considering all the facts, LQTS risk groups for life-threatening cardiac event may be categorized as high, intermediate and low (figure 2) (31). However, since the phenotypic expression is time-dependent and age specific, it requires continuous risk assessment in affected patients.

\section{Therapeutic consideration}

As previously mentioned, treatment approach relays on risk assessment and it might be complex. The initial phase involves lifestyle modifications - avoiding competitive sport and extreme exertion, for LQT1 patients even noncompetitive swimming (31); prompt electrolyte disorder corrections in diarrhea or vomiting; avoidance of medications known to prolong the QT interval (7). For patients with LQT2 is recommended preclusion of acoustic stimulation, such as alarm clock (17).

The first-line medical therapy involves $\beta$-blockers. They are presumed to act indirectly, through attenuation of cardiovascular adrenergic tone (7). The most effective have shown to be propranolol $(2-4 \mathrm{mg} / \mathrm{kg} /$ day $)$ and nadolol (1-1.5 mg/kg/day) (32).Widely used in LQT1 and LQT2, lately has been indicated protective role of $\beta$-blockers in LQT3 (33). They should be administered to all intermediate and high risk patients and according to some authors even to low-risk individuals (8). Possible adjunctive therapy might be oral $\mathrm{K}+$ supplementation, especially in LQT2 patients, whereas mexiletine and ranolazine effects for
LQT3 patients are still estimated in trials (34). However, in patients with repetitive cardiac events, a more invasive therapy should be considered.

Implantable cardioverterdefibrillator (ICD) is indicated for high-risk patients, post-cardiac arrest cases or those with numerous arrhythmic syncopal episodes who remain symptomatic despite $\beta$-blocker therapy, intoleration or contraindication for $\beta$-blockers, as well as JLN patients (27).

Left cervicothoracic sympathetic denervation (LCSD) is a surgical procedure of heart denervation by resection of left stellate ganglion and T2-T4 thoracic ganglia, introduced as treatment option even before medications (35). It is currently used for patients intolerant or irresponsive to $\beta$-blockers, patients in whom ICD implantation is unfeasible or who receive multiple ICD shocks (7).

Permanent pacemaker implantation is the last possible therapeutic option, combined with $\beta$-blocker therapy in patients with sinus bradycardia or pause-dependent TdP, but long-term follow-up studies still indicate an inappropriately high rate of SCD afterwards (36). Recent reports analyze focal radiofrequency ablation and gene-specific LQTS therapies as prospective therapeutic alternatives which appear to be promising.

\section{Recommendation for sport participation for children with LQTS}

It is proven in over $90 \%$ cases that cardiovascular diseases are the most important cause of sudden death in young athletes (37). Furthermore, incidence of SCD in young athletes is 2.5 times higher than the average rate of SCD (38). LQTS contributes with $2 \%$ in sudden cardiac death of young athletes in European population (38).

There are no official recommendations for physical activities in children with congenital LQTS, so they arise from the ones for adults. Cut-off values for prolonged QTc in athletes are $>470 \mathrm{~ms}$ for men and $>480 \mathrm{~ms}$ for women (39). The latest Bethesda recommendations for individuals with LQTS are: 1) for patients who experienced cardiac arrest or LQTS-precipitated syncopal episode are allowed only sports with low static and low dynamic intensity (class IA); 2) activities for asymptomatic patients with baseline QT prolongation should be restricted to class IA sport, except for genetically proven LQT3; 3) genotype-positive/phenotype-negative patient may be allowed to participate in competitive sports, except swimming for LQT1; 4) LQTS patients with an ICD/pacemaker should be restricted to class IA activities (table 4) (39). Considering such strict limitations, Aziz et al examined the consequences of neglecting the official recommendations and have not proven any cardiac event in LQTS children who 
Table 4. Classification of sports (36).

\begin{tabular}{|c|c|c|c|}
\hline & A. Low dynamic & B. Moderate dynamic & C. High dynamic \\
\hline I Low static & $\begin{array}{l}\text { Bowling } \\
\text { Cricket } \\
\text { Golf } \\
\text { Riflery }\end{array}$ & $\begin{array}{l}\text { Fencing } \\
\text { Table tennis } \\
\text { Tennis (doubles) } \\
\text { Volleyball } \\
\text { Baseballa/softball }^{\mathrm{a}} \\
\text { Field events (jumping) }^{\text {Figure skating }}\end{array}$ & $\begin{array}{l}\text { Badminton } \\
\text { Race walking } \\
\text { Running (marathon) } \\
\text { Cross-country skiing (classic) } \\
\text { Squash }^{\text {a }} \\
\text { Basketball }^{\mathrm{a}} \\
\text { Biathlon }^{\text {Batlon }}\end{array}$ \\
\hline II Moderate static & $\begin{array}{l}\text { Auto racing } \\
\text { Diving }^{\mathrm{a}, \mathrm{b}} \\
\text { Equestrian }^{\mathrm{a}, \mathrm{b}} \\
\text { Motorcycling }^{\mathrm{a}, \mathrm{b}} \\
\text { Gymnastics }^{\mathrm{a}} \\
\text { Karate/Judo }^{\mathrm{a}} \\
\text { Sailing } \\
\text { Archering }\end{array}$ & $\begin{array}{l}\text { Lacrosse }^{\mathrm{a}} \\
\text { Running (sprint) }\end{array}$ & $\begin{array}{l}\text { Ice hockey }^{\mathrm{a}} \\
\text { Field hockey }^{\mathrm{a}} \\
\text { Rugby }^{\mathrm{a}} \\
\text { Soccer }^{\mathrm{a}} \\
\text { Cross-country skiing(skating) } \\
\text { Running (mid/long) } \\
\text { Swimming } \\
\text { Tennis (single) } \\
\text { Team handball }^{\mathrm{a}} \\
\text { Boxing }^{\mathrm{a}}\end{array}$ \\
\hline III High static & $\begin{array}{l}\text { Bobsledding }{ }^{\mathrm{a}, \mathrm{b}} \\
\text { Field events (throwing) }_{\text {Luge }^{\mathrm{a}, \mathrm{b}}} \\
\text { Rock climbing }^{\mathrm{a}, \mathrm{b}} \\
\text { Waterskiing, }^{\mathrm{a}, \mathrm{b}} \\
\text { Weight lifting }^{\mathrm{a}} \\
\text { Windsurfing }^{\mathrm{a}, \mathrm{b}}\end{array}$ & $\begin{array}{l}\text { Body building }^{\mathrm{a}} \\
\text { Downhill skiing } \\
\text { Wrestling } \\
\text { Snow boarding } \\
\text { a,b }\end{array}$ & $\begin{array}{l}\text { Canoeing, Kayaking } \\
\text { Cyclinga, } \\
\text { Decathlon } \\
\text { Rowing } \\
\text { Speed skating } \\
\text { Triathlon }{ }^{\mathrm{a}, \mathrm{b}}\end{array}$ \\
\hline
\end{tabular}

a - danger of bodily collision; $\mathrm{b}$ - increased risk if syncope occurs

were on beta-blocker therapy or with implanted ICD (40). These results suggest that the initial limitations might be too harsh, which implicates the need for further analysis.

\section{Conclusion}

Previous investigations of LQTS have broadened our knowledge, but have also raised many questions about the pathogenesis, diagnosis and treatment of these syndromes. Further genetic researches are expected to advance the understanding of genotype-phenotype correlation, provide novel insight into rare LQTS types and enable eventual genetically-guided personalized treatment in future. The relation between physical activity and LQTS manifestations is widely proven, since the first phase of LQTS treatment is avoiding competitive sport . Considering the differences among LQTS types, it is reasonable to presume more precise recommendations for physical activity of LQTS children.

\section{References:}

1. Amin AS, Pinto YM, Wilde AA. Long QT syndrome: beyond the causal mutation. J Physiol. 2013 Sept; 591(17):4125-39.

2. Kallergis EM, Goudis CA, Simantirakis EN, Kochiadakis GE, Vardas $P E$. Mechanisms, risk factors, and management of acquired long QT syndrome: a comprehensive review. Scientific World Journal. 2012;2012:212178
3. Mizusawa Y, Horie M, Wilde AA. Genetic and clinical advances in congenital long QT syndrome. Circ J. 2014 Dec; 78(12):2827-33.

4. Schwartz PJ, Stramba-Badiale M, Crotti L, Pedrazzini M, Besana A, Bosi G et al. Prevalence of the congenital long-QT syndrome. Circulation. 2009 Nov; 120:1761-7.

5. Arnestad M, Crotti L, Rognum TO, Insolia R, Pedrazzini M, Ferrandi C et al. Prevalence of long-QT syndrome gene variants in sudden infant death syndrome. Circulation. 2007 Jan; 115:361-7.

6. Tester DJ, Will ML, Haglund CM, Ackerman MJ. Effect of clinical phenotype on yield of long QT syndrome genetic testing. J Am Coll Cardiol. 2006 Feb; 47:764-8.

7. Brenyo AJ, Huang DT, Aktas MK. Congenital long and short QT syndromes. Cardiology. 2012 April; 122(4):237-47.

8. Goldenberg I, Moss AJ. Long QT Syndrome. J Am Coll Cardiol. 2008 June; 51(24):2291-300.

9. Antzelevitch C, Shimizu W, Yan GX, Sicouri S, Weissenburger J, Nesterenko VV et al. The $M$ cell: its contribution to the ECG and to normal and abnormal electrical function of the heart. J Cardiovasc Electrophysiol. 1999 Aug; 10:1124-52.

10. Amin AS, Asghari-Roodsari A, Tan HL. Cardiac sodium channelopathies. Pflugers Arch. 2010 Jul; 460:223-37.

11. Antzelevitch C. The Role of Spatial Dispersion of Repolarization in Inherited and Acquired Sudden Cardiac Death Syndromes. Am J Physiol Heart Circ Physiol. 2007 Oct; 293(4):2024-38.

12. Schwartz PJ, Spazzolini C, Crotti L, Bathen J, Amlie JP, Timothy K et al. The Jervell and Lange-Nielsen syndrome: natural history, molecular basis, and clinical outcome. Circulation. 2006 Feb; 113: 783-90.

13. Sansone V, Tawil R. Management and treatment of Andersen-Tawil syndrome (ATS). Neurotherapeutics. 2007 Apr; 4:233-7.

14. Splawski I, Timothy KW, Sharpe LM, Decher N, Kumar P, Bloise R et al. $\mathrm{Ca}(\mathrm{V}) 1.2$ calcium channel dysfunction causes a multisystem disorder including arrhythmia and autism. Cell. 2004 Oct 1; 119(1):19-31. 
15. Wu J, Naiki N, Ding WG, Ohno S, Kato K, Zang W-J et al. A molecular mechanism for adrenergic-induced long QT syndrome. J Am Coll Cardiol. 2014 March; 63(8):819-27.

16. Choi G, Kopplin LJ, Tester DJ, Will ML, Haglund CM, Ackerman MJ. Spectrum and frequency of cardiac channel defects in swimming-triggered arrhythmia syndromes. Circulation. 2004 Oct; 110(15):2119-24.

17. Schwartz PJ, Priori SG, Spazzolini C, Moss AJ, Vincent GM, Napolitano $C$ et al. Genotype-phenotype correlation in the long-QT syndrome: gene-specific triggers for life-threatening arrhythmias. Circulation. 2001 Jan; 103:89-95.

18. Johnson JN, Hofman N, Haglund CM, Cascino GD, Wilde AA, Ackerman MJ. Identification of a possible pathogenic link between congenital long QT syndrome and epilepsy. Neurology. 2009 Jan; 72:224 - 231.

19. Rautaharju PM, Surawicz B, Gettes LS, Bailey JJ, Childers R, Deal BJ et al. AHA/ACCF/HRS recommendations for the standardization and interpretation of the electrocardiogram. Part IV: the ST segment, T and U waves, and the QT interval. J Am CollCardiol. 2009 Mar; 53(11):982-91.

20. Goldenberg I, Moss AJ, Zareba W. QT interval: how to measure it and what is "normal." J Cardiovasc Electrophysiol. 2006 Mar; 17:333- 6.

21. Goldenberg I, Horr S, Moss AJ, Lopes CM, Barsheshet A, McNitt S et al. Risk for life-threatening cardiac events in patients with genotype-confirmed long-QT syndrome and normal-range corrected QT intervals. J Am Coll Cardiol. 2011 Jan; 57:51-9.

22. Moss AJ, Zareba W, Benhorin J, Locati EH, Hall WJ, Robinson JL et al. ECG T-wave patterns in genetically distinct forms of the hereditary long QT syndrome. Circulation. 1995 Nov; 92:2929-34.

23. Sumitomo N. Clinical Features of Long QT Syndrome in Children. Circ J. 2016 Feb; 80(3):598-600.

24. Aziz PF, Wieand TS, Ganley J, Henderson J, Patel AR, lyer VR et al. Genotype- and mutation site-specific QT adaptation during exercise, recovery, and postural changes in children with long-QT syndrome. J Circ Arrhythm Electrophysiol. 2011 Dec;4(6):867-73.

25. Tester DJ, Ackerman MJ. Genetics of long QT syndrome. Methodist Debakey Cardiovasc J. 2014 Jan-Mar;10(1):29-33.

26. Schwartz PJ, Crotti L, Insolia R. Long-QT syndrome: from genetics to management. CircArrhythmElectrophysiol. 2012 Aug;5(4):868-77.

27. Priori SG, Wilde AA, Horie M, Cho Y, Behr ER, Berul C et al. Heart Rhythm Society; European Heart Rhythm Association; Asia Pacific Heart Rhythm Society. Executive summary: HRS/EHRA/APHRS expert consensus statement on the diagnosis and management of patients with inherited primary arrhythmia syndromes. Europace. 2013 Oct; 15(10):1389-406.

28. Locati EH, Zareba W, Moss AJ, Schwartz PJ, Vincent GM, Lehmann MH et al. Age- and sex-related differences in clinical manifestations in pa- tients with congenital long-QT syndrome: findings from the International LQTS Registry. Circulation. 1998 Jun; 97:2237- 44.

29. Abehsira G, Bachelot A, Badilini F, Koehl L, Lebot M, Favet C et al. Complex influence of gonadotropins and sex steroid hormones on QT interval duration. J Clin Endocrinol Metab. 2016 May:jc20161877.

30. Hobbs JB, Peterson DR, Moss AJ, McNitt S, Zareba W, Goldenberg I et al. Risk of aborted cardiac arrest or sudden cardiac death during adolescence in the long-QT syndrome. JAMA. 2006 Sep;296:1249-54.

31. Moss AJ, Zareba W, Hall WJ, Schwartz PJ, Crampton RS, Benhorin J et al. Effectiveness and limitations of beta-blocker therapy in congenital long-QT syndrome. Circulation. 2000 Feb; 101:616-23.

32. Chockalingam P, Crotti L, Girardengo G, Johnson JN, Harris KM, Van der Heijden JF et al. Not all beta-blockers are equal in the management of long QT syndrome types 1 and 2: Higher recurrence of events under metoprolol. J Am Coll Cardiol. 2012 Nov; 60: 2092-9.

33. Wilde A, Kaufman E, Shimizu W, Moss A, Benhorin J, Lopes CM et al. Sodium channel mutations, risk of cardiac events, and efficacy of beta-blocker therapy in type 3 long QT syndrome. Heart Rhythm. 2012; 9: S321.

34. Antzelevitch C, Burashnikov A, Sicouri S, Belardinelli L. Electrophysiologic basis for the antiarrhythmic actions of ranolazine. Heart Rhythm. 2011 Aug; 8:1281-90.

35. Schwartz PJ, Priori SG, Cerrone M, Spazzolini C, Odero A, Napolitano $C$ et al. Left cardiac sympathetic denervation in the management ofhigh-risk patients affected by the long-QT syndrome. Circulation. 2004 Apr; 109:1826-33.

36. Passman R, Kadish A. Sudden death prevention with implantable devices. Circulation. 2007 Jul; 116(5):561-71.

37. Maron BJ. Hypertrophic cardiomyopathy and other causes of sudden cardiac death in young competitive athletes, with considerations for preparticipation screening and criteria for disqualification. Cardiol Clin. 2007 Aug; 25(3):399-414, vi.

38. Corrado D, Basso C, Rizzoli G, Schiavon M, Thiene G. Does sports activity enhance the risk of sudden death in adolescents and young adults? J Am Coll Cardiol. 2003 Dec 3;42(11):1959-63.

39. 36th Bethesda Conference: Eligibility Recommendations for Competitive Athletes With Cardiovascular Abnormalities. Task force 7: Arrhythmias. Zipes DP, Ackerman MJ, Estes NA 3rd, Grant AO, Myerburg RJ, Van Hare G et al. J Am Coll Cardiol. 2005 Apr; 45:1354-63.

40. Aziz PF, Sweeten T, Vogel RL i sar. Sports Participation in Genotype Positive Children With Long QT Syndrome. JACC Clin Electrophysiol. 2015 Mar-Apr;1(1-2):62-70. 